TJSS|

DOI: $10.30520 /$ tjsosci.954512

\title{
HUMAN RIGHTS IN UN COUNTER-TERRORISM DEBATE: IMPERATIVE OR IMPEDIMENT
}

\author{
Iffat NAHEED ${ }^{1}$
}

\begin{abstract}
"The war on terrorism" that was declared by the international community in the aftermath of 9/11 created a state of emergency. As a result, United Nations Security Council established the fact that the international peace and security should be the first and foremost on its priority list of agendas. UN Security Council created its subsidiary bodies to deal with counter terrorism but it failed to take human rights into consideration in the beginning. Initially, the procedures of UN Security Council committees gathered a criticism on account of causing damage to human rights laws, freedom of life and humanitarian laws. As a result, the procedures of committees evolved with passage of time to ensure that the counter terrorism measures are in accordance with human rights and humanitarian laws. This article provides an overview of the progress that gradually resulted in the prominence of human rights by UN Security Council committees and Human Rights Council. Recently, there has been initiated a debate again that the human rights protection is a hindrance in countering terrorism effectively and the opposition of human rights protection laws argue that there should be declared a state of emergency in a country to completely eliminate the threat of terrorism. The article also provides an overview of the ongoing debate on human rights as to what extent this debate proves to be an imperative or impediment suggesting a mixed and balanced approach as neglecting the human rights completely can cause more tragic situation than terrorism on one hand, however, on the other hand, there is a need to restrict some of the liberties as terrorists utilize those human rights and liberties to cause havoc in the world.
\end{abstract}

Keywords: Human Rights Violation; Human Rights Protection;War on terrorism; Insurgency; Humanitarian Law; Counter-terrorism

\footnotetext{
${ }^{1}$ Iffat Naheed is a PhD student at the National University of Political Studies and Public Administration, Bucharest, Romania (irtiqaa86@gmail.com)
} 


\section{INTRODUCTION}

Universal Declaration of Human Rights (UDHR) is binding on all the member states of United Nations, a document which is a milestone in the human history of fundamental human rights and it is created by legal and cultural experts from diverse regions of the world. It was proclaimed by General Assembly in 1948 in a General Assembly resolution 217 A (III).All the human beings deserve the fundamental human rights and freedoms. Being different in physical appearance, skin shade, origin and back ground does not matter at all. All the 30 articles of UDHR describe the basic human rights and freedoms that are equally enjoyable for all humans and are universally protected. There is also another division of liberties called civil liberties which provides protection against any action by the government to the citizens of a nation state within the state. So, the human rights are not bound to any discrimination of ethnicity, race, nationality, sex or religion but the civil liberties are bound to a nation state.(Nations, UDHR, 1948).

There are certain obligations that are laid down by International human rights law according to which governments are bound to take actions in certain ways to protect fundamental human rights and need to abstain from certain actions that can deviate from human rights.

The respect for human rights has been a major concern during the war against terrorism. The struggle of countering terrorism has actually originated violations of human rights not only by the terrorists but also by the state officials involved in counter terrorism measures. With the increase in the international concern over the acts of terrorism, there has been observed a parallel rise in consciousness that the counter terrorism actions themselves provided the risk of encroaching on human rights (Flynn, 2007). This concern was accelerated after 9/11.Governments tend to violate human rights in good faith in case of emergencies when the security becomes at stake. This increasing concern resulted in formation of international human rights instruments with measures that have been subject to certain limits to avoid discrimination and to respect the values of legality and proportionality and also to remind states that the rights to live with freedom in absence of any kind of torture and ill-treatment should be non-derogable even in critical situations.

This situation gave rise to a debate on Human Rights aspect of the "war against terrorism" and created two parties; one of which is adamant of protection of Human Rights, Liberties of human beings and respect of Humanitarian laws during the "Fight against Terrorism"; the other party is of the view that the terrorists are such a great threat to Human life and peace in the world that the states should go beyond any limit to make the world free of terrorists and terrorism. This paper has the main objective to put forth some of the imperatives as well as impediments of the ongoing debate on protection of Human Rights during counter terrorism activities. For this purpose, some of the literature will be reviewed in this research paper to put forth the argumentation of both the groups who are of the view to vanish terrorists at any cost and of those who stand against the view that human protection should be ensured at the cost of human liberty and freedom.

Paul Hoffman (Hoffman, 2004)believes that the human rights norms are as important and valid today as those were in 2001. It is vital to follow human rights principles and framework in order to secure our lives and freedom and it cannot inhibit our struggle and effective efforts to 
fight against terrorism.In case, the human rights are traded with security, there is great possibility that neither will be achieved. When the human rights are violated, the minorities usually pay the price of it. Sometimes it results in genocide or suppression of a religion. So, under-estimating the value of international human rights law will only undermine the counter terrorism efforts. Also, if the state is failed to ensure the respect of basic human rights, there would be more chances for the terrorist organizations of recruiting their supporters among the effected families whose rights have been grasped. The efforts to minimize the threat of terrorism can be effectively successful by decreasing the human rights violations that occur in the name of fighting terrorism. It can benefit the fight against terrorism in the short and long run.However, the abuse of human rights laws can undermine the public support and mutual cooperation, vital for countering terrorism because there is no nation that can fight terrorism on its own without cooperation.

Tufft (Tufft, 2015) describes that Charlie Hebdo Paris attack in 2015 initiated a debate about setting up priorities for the security of people in following counter terrorism measures. David Davies who was a police constable had been involved in counterterrorism operations. He was of the view that the human rights create a hindrance in the counter terrorism operations and terrorists should not get the protection of human rights. He was adamant of scrapping off the human rights for the complete protection of people and make the state free of terrorists. His statement came when he arrested a person who claimed himself as a member of Taliban and he was on asylum in UK. MP stated "Anyone suspected of links with any militant Islamist organizations should be prevented from entry under any circumstance into Britain." His statement was opposed by human rights experts and called as legal illiteracy.

London Bridge Terrorist attacks in 2017 revived the debate. British Prime Minister, Theresa May in 2017, gave the statement that she will change the human rights laws to crackdown the terrorists for complete security from terrorist attacks. She said that she wanted to make it easier to deport all the foreign terrorist suspects. According to Mason and Dodd (Dodd, 2017), she wanted to rip up the human rights laws to provide a complete security from terrorists and she was of the view that human rights protection laws are complete hindrance in taking action against suspected terrorists.

\section{THEORETICAL FRAMEWORK}

The study is focused on the issue of human rights protection during the critical circumstances when the international community needs to be united against terrorism under the flag of United Nations and a war on terrorism is declared. During this struggle against terrorism the measures taken by the United Nations and the international community have continuously raised the question of human rights protection and the difficulties caused by the human rights laws in countering terrorism are also being questioned for disrupting the process for fruitful results. As the following article presents the outcome of this debate on the UN counter terrorism actions.

The study is based on the qualitative research methodology which is carried out by library research and the method of document analysis (Kothari 2004). The research approach is analytical utilizing the technique of content analysis. The research is in support of institutionalism and gives an overview of the work and efforts taken by United Nations and its 
different bodies in this context. However, the failures that United Nations encountered in this regard need to be highlighted for the improvement of institutions so as to achieve the best possible results in spite of the Global politics and other complications. International cooperation against terrorism has increased progressively with the passage of time and United Nations has adapted itself for the tasks of counter terrorism in unprecedented manner(Romaniuk 2010). This multilateral cooperation has evolved as international regime which not only permits states to make required changes in domestic policies but also demand for a cooperation with other states(Sasikumar 2010).

9/11 attacks had caused a recalibration of counter terrorism methods, derogation principles needed to be redefined and refugee's protection had to be decreased (Fitzpatrick, 2003). It was a completely new scenario when the state of affairs took the form that citizens not only needed a protection from the terrorist threat but also from the government who was fighting the terrorism. This is the irony of $21^{\text {st }}$ century (Hardin, 2004). According to the new threats, new methods of law enforcement needed to be applied(Onwuchekwe Pius Tobechukwu, 2019).

Laborde emphasizes on "proactive law enforcement" in contrast to "reactive law enforcement" which means to prevent and interrupt crime instead of reacting to a crime which is already committed. Terrorism is a major crime so there should be more attention in preventing terrorism to greater extent. So, in designing a successful and effective strategy to counter terrorism would require a proactive criminal justice approach provided with planning and preparation to destroy a terrorist plan before it matures and comes into action. According to this explanation terrorism needs to be countered through penal prevention which means an act needs to be criminalized before being committed. This trend of criminalizing the act of terrorism regardless whether it actually takes place or not has the potential of attracting a criticism from human rights defenders and activists (Laborde, 2005).

UNSC resolution 1373 (2001) focuses a lot on this proactive criminal justice approach. The prevention and suppression of financing of terrorist activity demands from the states to take necessary actions to prevent the terrorist from committing any such activity through early warning by providing the early information to other states. It also includes denying safe havens to those who can finance, plan, support, facilitate or commit terrorist acts preventing them from using their respective territories for terrorist activities against other states or their citizens (Laborde, 2005).UNSC in its resolution 1624 (2005) further added incitement to the list of offences when it calls upon states to adopt the necessary measures. This legislation contradicts international human rights standards. It seems a never-ending debate. In the countries with a weaker justice system, this type of offences is at risk of misuse politically and contradict to the norms of international human rights. As, protection of life is also prevention of its loss which supports the argument that interruption of any preparations for terrorist attacks and brutality is crucial for the safety of life which is a fundamental human right.

Tobechukwu calls the "reactive law enforcement " as "due process model" and "proactive law enforcement" as "crime control model" of justice system. According to him, in order to eliminate terrorism more effectively without giving any harm to human rights and liberties of the individuals, there is a need of incorporating both the models of justice system in the legislation. Though defenders of human rights rely on due process but the crime control system is an 
efficient method to maintain law and order and it justifies some infringements on human rights to extract useful information for countering terrorism (Onwuchekwe Pius Tobechukwu, 2019).

\section{HUMAN RIGHTS VIOLATIONS IN THE NAME OF "WAR ON TERRORISM"}

The status of "war on terrorism" of being a real war or not has posed a serious challenge to design a human rights framework.As war can be considered as an emergency that can be excluded from the effect of human rights laws. An important element in making a human rights framework is the fact that there should not be any area with zero influence of human rights and also human rights are applicable on each individual for just being a human. There has been a situation of uncertainty created by some states like United States presented the "war on terrorism" being free from constraints of international law and it caused a continuous damage to the individual rights and created certain ambiguities about it (Fitzpatrick, 2002). There are countless examples where United States tried to eliminate the protection of human rights law by labelling the acts of counter terrorism as fighting a real war and represented it as being a part of a parallel legal world where there is no respect for legal norms nullifying the effect of any diplomatic and public relation in that specific area. Without defining any geographic and temporal scope of this war, it is spread on the whole planet regardless of any borders and sovereignty of states. Human rights protectioncontradicts with imperatives of war on terrorism.

"All of us have difficulty with the idea that although we are all different, we all should be treated the same. It seems 'natural' to ascribe negative meanings to differences, to associate difference with the supposedly inferior or superior or the dangerous. It is not, however, natural. It is something we learn and is therefore something we can unlearn" (OHCHR, 2005). The war on terrorism created a discrimination that minorities had to suffer mainly which was not only very unfair and unjustified but also proved to be damaging to the security efforts. As an example, United States, after 9/11, arrested many Muslims and Arab Nationals and detained them secretly as a preventive measure against terrorism. There was no bail acceptance for detainees by the government. They were charged with criminal offences heavily and kept under harsh conditions. Such racial discrimination could result only in anger and a feeling of exclusion. Based on minor violations of immigration law, thousands of non-citizens with certain national or religious background were detained even they had remotely any connection to terrorism. By such actions, the ineffectiveness of counter terrorism strategies and collateral damage related to the "war on terrorism" was evident (Hoffman, 2004).

David Cole has put forth a comprehensive assessment of the different ways in which the war on terror has put the citizens of US to the threat of more insecurity rather than peace. He argues that the action that were taken by the authorities in US in the name of national security since 9/11have not only sacrificed the liberty of non-citizens but also put the security and liberty of all citizens at risk (Cole, 2003). Similarly, the abuse of counter terrorism powers against minorities and non-citizens was also observed in other countries like United Kingdom. Such actions proved to be counter productive in fighting terrorism effectively and creation of peace and security and also caused enmity against authorities from the affected people. Studies have shown that respect for human rights is not only the right thing to do but also it is crucial to get maximum security protection for everyone (Hoffman, 2004). 
Insurgency or internal conflict is one of the greatest challenges that $21^{\text {st }}$ century has to face. Insurgencies end up in countless people becoming refugees or are internally displaced. The displacement of persons is clearly a biggest violation of human rights. There is still much room for developing a powerful institution with a full mandate of curbing the human rights violations within the boundaries of a nation state. It is evident from the activities of Boko Haram posing a serious threat to Nigerian security. Due to the mayhem caused by many causalities of the civilians and security persons, the Nigerian government pursued counter terrorism activities against Boko Haram (Blanchard, 2014). It established a special task force (JTF) to annihilate them. The Nigerian Security forces as well as Boko Haram were indicted with war crimes by media and human rights organizations. The Counter Terrorism Implementation Task Force (CTITF) came to rescue which was appointed by the government to curtail human rights violations against civilians. CTITF could not play a significant role in protecting human rights and bringing a change in human rights violations (Tasiu Magaji, 2018).

\section{THE ROLE OF UNITED NATIONS IN HUMAN RIGHTS PROTECTION DURING THE STRUGGLE AGAINST TERRORISM}

United Nations Security council (UNSC) has performed an active role in countering terrorism. The struggle of UNSC against terrorism is evident in the form of two significant resolutionsi.e., Resolution 1267(S/RES/1267, 1999)and 1373(S/RES/1373, 2001) and the committees established under these resolutions. Initially, a slight concern by UNSCabout the human rights was observed but later the focus on the human rights aspect was re-established that resulted in more emphasis and commitments by the UN to human rights (Flynn, 2007).

Security Council Resolution 1267 which was passed in October 1999 had imposed obligatory financial and aviation sanctions on Talibans in Afghanistan and all the fifteen members of the committee established under this resolution had the responsibility to implement these sanctions. Later, the scope of the sanctions was increased which involved financial and travel restrictions on Talibans, Al-Qaeda and all of them who were linked to that organization wherever they were located. As a main task of the 1267 Committee, the names of the Taliban or Al-Qaeda associates were supposed to be on a consolidated list based on the information provided by the member states. In case of any names wrongly listed, the accused had the right to request to its state of residence or citizenship to appeal on its behalf which could be denied (Rosand, 2004).

After 9/11, Security Council Resolution 1373 was passed which imposed comprehensive legal obligations on UN member states. The states had obligations to freeze the assets and reject the terrorists safe haven, amend laws, control arms and exchange information about terrorists with other states in order to provide judicial assistance in terrorism related proceedings(David Cortright, 2004). The Counter Terrorism Committee (CTC) is also comprised of all the fifteen members of the Security Council and it was established to monitor the implementation of all the obligations on states. This was done by providing reports by the states about all the legislative measures taken by the states.

Both the committees under Resolutions 1267 and 1373 had some areas in common and work independently. Proficient groups under these committees had been more autonomous and report on a regular basis on their work and findings. Besides some commonalities, the committee under 


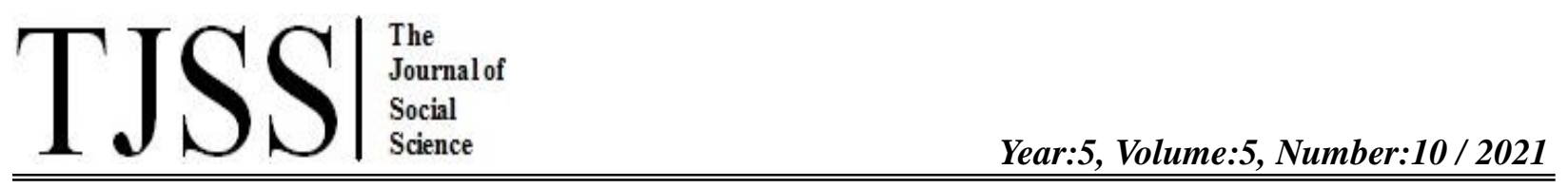

Resolution 1267 imposes constraints on persons named as terrorists and carries out coercive measures but 1373pursues to institute the standards to prevent and deter terrorism. It also proceeds to find and prosecute terrorists. CTC works as a technical body which works together with the states instead of working against them to provide help in training by the states having capability to assist through practical advice. This might be the reason that states want to submit their reports to CTC rather than 1267 Committee (Foot, 2007).

Security Council Resolution 1267 gained a lot of criticism because it was failed to give heed to human rights though it had made a lot of noise about violation of human rights by Talibans. It was also criticized for its process of listing and delisting of terrorists. However, Resolution 1373 was also criticized for not making it clear in its counter terrorist measures to regard the international human rights law. There had been observed a complete negligence of human rights outcomes of the "war on terror" by the committees as if war against terrorism might be successful at the cost of human rights and freedom. There were no legal standards provided by any Security Council Resolution for the inclusion or deletion of individuals or groups to or from the lists for those which are added mistakenly on the lists or were missed out to be included on the lists (Rosand, 2004).

It was also observed by the human rights experts during the report submission by the states that CTC paid no attention on the human rights abuse in drafting counter terrorism or security legislation and also on human rights implications. This was an important element in reports submitted by different countries in targeting refugees, migrants, asylum seekers, media, political activists and minorities. The first chair of CTC took the argument that human rights matters were not of direct concern to CTC. Instead, the other UN bodies carry the main responsibility to deal with human rights implications of its actions against terrorism.

The UNSC resolution 1456(S/RES/1456 , 2003) called on CTC to ensure that its measures against terrorism should be in compliance with human rights and humanitarian laws in addition to intensify its working to take action in accordance with the resolution 1373 . This stress on human rights was repeated in resolutions 1566(S/RES/1566, 2004) and 1624(S/RES/1624, 2005).

The former Secretary General Kofi Annan being a great advocate of giving more respect to human rights and priority to individuals over state sovereignty had established a policy working group on terrorism and a sub group on its human rights impacts which gave human rights a significant position in efforts for countering terrorism. He spoke against approving every kind of measures taken by the states that mislead and confuse the term "counter terrorism". He stressed on the need of improving democratic governance in implementing the measures under CTC and the targeted sanctions instead of undermining it. Resolution 1456 unlike 1373 stressed a lot on the respect and protection of human rights and it was declared by the late High Commissioner for Human Rights, Sergio Vieira de Mello that CTC must consider the fostering of social justice, democracy and ensuring the supremacy of international law.

Though, resolution 1456 stressed that CTC should consider the human rights implications of counter terrorism but it failed to address the mandate of CTC and left an ambiguity as to whether 
CTC could inquire those matters or not. The adoption of resolution 1535 helped in bringing mandates of CTC regarding human rights into the spotlight. It was a mandate of CTC to become proactive in supervising the implementation of resolution 1373 and also approved a blueprint which was proposed by the then chairman of CTC Ambassador InocencioArias of Spain.

In 2004 CTC was revitalized and an expert on Human rights and refugee law was appointed to help coordinating with OHCHR and human rights NGOs and also improvements in listing and de-listing procedures were recommended. The term Al-Qaida association was elaborated along with the criteria for identification of individuals and groups by the Monitoring team(S/2004/124 Council, 2004).

With the revitalization of CTC, Counter Terrorism Committee Executive Directorate (CTED) was established having a full responsibility of assisting CTC for its monitoring work(S/RES/1535, 2004). CTED performed as a broker between states which had difficulties in implementation of resolution 1373 and the states that had performed well. It also enabled CTC to have site visits with the consent of the states to provide detailed assistance.It helped greatly to provide required technical assistance to the states in strengthening their counter terrorism regime. It also helped to establish a team of experts called Assessment and Technical Assisstance Office (ATAO) to help states in implementation of the resolution. ATAO had the mandate of coordinating with OHCHR and other human rights organizations for the terrorism related issues in addition to many other duties (S/2004/124 Council, 2004).

The Counter Terrorism Task Force (CTITF), established in 2005, has the responsibility to ensure coherence and coordination in performing activities related to counter terrorism by all the UN bodies. It also assists and provides support to all the member states in implementing UN Global Counter Terrorism Strategy (UNGCTS-2006). As GCTS is mainly based on four pillars, one of which is "Measures to ensure respect for human rights for all and the rule of law as the fundamental basis of the fight against terrorism". To promote the international cooperation for countering the terrorism, there was established the United Nations Counter Terrorism Centre (UNCCT) in 2011 (CTITF, 2014).

\section{CONCLUSION}

The above study shows that "war on terrorism" certainly brought infringements of fundamental human rights and humanitarian laws. It brought a wave of racism, discrimination along with many insecurities for the citizens of a country especially non nationals living in other countries. The debate about human rights that resulted from this scenario certainly has its imperatives. Along with the protection and security from terrorism, also the security of human rights and liberties of the individuals are equally important and need to be carefully considered during counter terrorism efforts by United Nations and governments of the states. It is also difficult to eliminate the threat of terrorism in an effective manner if the fundamental rights of individuals are undermined because there is more possibility of abuse of powers by the governments if human rights are not fully protected internationally and institutionally. It will also result in producing more terrorists from the effected or wrongly accused persons. 


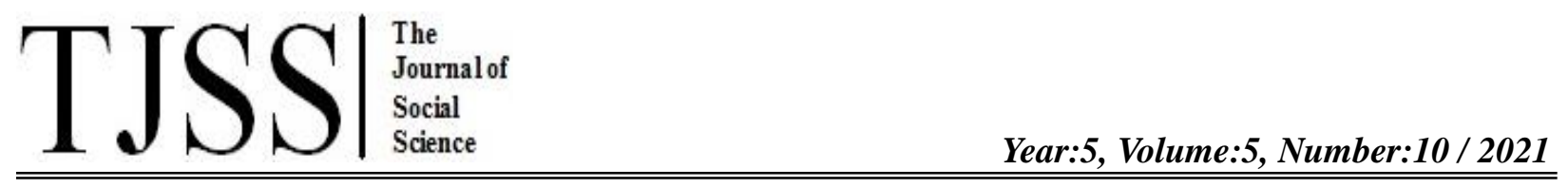

The research paper also shows that the risk of mass destruction has resulted in a shift of justice system from due process to crime control model. It seems that crime control is more efficient than due process but it brings the violation of the human rights and civil liberties. However, a mixed approach is required to achieve the security of both the lives and liberties which calls for more stress on human rights protection along with some amendments during formation of counter terrorism legislation and security system.

This also shows that United Nations has adapted progressively in the context of human rights protection in adopting and implementing different resolutions for countering terrorism. However, some failures in achieving the maximum outcome does not go completely against institutions and suggests that more efforts in gaining transparency, independence from certain powerful states and equality are required in passing and implementing the resolutions.

\section{REFERENCES}

1. Blanchard, L. P. (2014). Nigeria's Boko Haram: Frequently asked Questions. Lauren Ploch Blanchard Specialist in African Affairs . Congregational Research Service.

2. Cole, D. (2003). Enemy Aliens, Double Standards and Constitutional Freedoms in the War on >Terrorism. New York: The New Press.

3. Council, U. N. (1999, October 15). S/RES/1267.

4. Council, U. N. (2001, September 28). S/RES/1373.

5. Council, U. N. (2003, January 20). S/RES/1456 .

6. Council, U. N. (2004). S/RES/1535. United Nations.

7. Council, U. N. (2004, October 08). S/RES/1566.

8. Council, U. N. (2005, September 14). S/RES/1624.

9. CTITF, C. T. (2014, October). Working Group on protecting human rights while countering terrorism, Basic Human Rights Reference Guide. New York: United Nations.

10. David Cortright, G. A. (2004, September). An Action Agenda for Enhancing the United Nations Program on Counter Terrorism. Washington D.C.: Fourth Freedom Forum.

11. Dodd, R. M. (2017, June 6). General Election 2017. Retrieved from The Guardian: https://www.theguardian.com/politics/2017/jun/06/theresa-may-rip-up-human-rights-laws-impede-newterror-legislation

12. Fitzpatrick, J. (2002). Sovereignty, territoriality and the rule of law. 25 Hastings Int'l \& Comp. L.

13. Fitzpatrick, J. (2003). Speaking Law to Power: The War Against Terrorism and Human Rights. European Journal of Law, 241-264. 


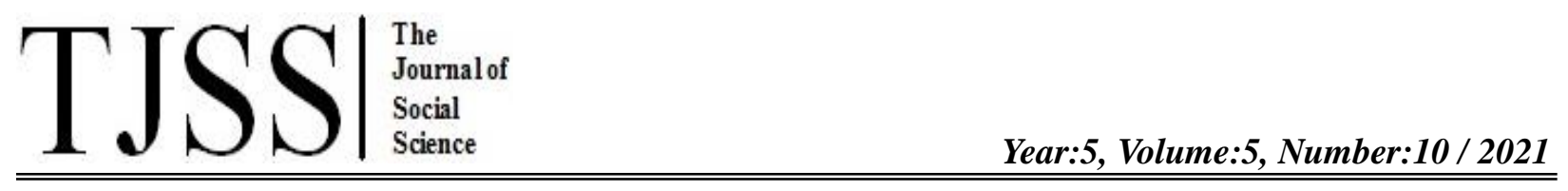

14. Flynn, E. J. (2007). The Security Council's Counter Terrorism Committee and Human Rights. Human Rights Law Review, 371-384.

15. Foot, R. (2007). The United Nations, Counter Terrorism and Human Rights: Institutional Adaptation and Embedded Ideas. Human Rights Quarterly, 489-514.

16. Hardin, R. (2004). Civil Liberties in the Era of Mass Terrorism. The Journal of Ethics, 77-95.

17. Hoffman, P. (2004). Human Rights and Terrorism. Human Rights Quaterly, 932-955.

18. Kothari, C. R. (2004). Research Methodology, Methods and Techniques. New age international publishers.

19. Laborde, J. P. (2005). Counter Terrorism: New International Criminal Laws Perspectives. Work product of the 132nd International Senior Seminar, UNODC. Austria.

20. Nations, U. (n.d.). Retrieved from https://undocs.org/en/A/RES/217(III)

21. Nations, U. (n.d.). Peace, dignity and equality on a healthy planet. Retrieved from Universal declaration of human rights: https://www.un.org/en/about-us/universal-declaration-of-human-rights

22. Nations, U. (n.d.). United Nations, Peace, dignity and equality on a healthy planet. Retrieved from Global issues, human rights: https:/www.un.org/en/global-issues/humanrights\#: :text=Human $\% 20$ rights $\% 20$ are $\% 20$ rights $\% 20$ inherent,and $\% 20$ education $\% 2 \mathrm{C} \% 20$ and $\% 20$ many $\%$ 20more.

23. OHCHR, U. (2005). Dimensions of Racism. Newyork and Geneva: United Nations.

24. Onwuchekwe Pius Tobechukwu, O. F. (2019). Civil Liberty, Human Rights and Security vs. Counter Terrorism Measure. The IUP Journal of International Relations, 26-40.

25. Romaniuk, P. (2010). Institutions as swords and shields. Review of International studies, 591-613.

26. Rosand, E. (2004). The Security Council's Efforts to Monitor the Implementation of Al-Qaeda/Taliban Sanctions. American Journal of International Law, 745-763.

27. S/2004/124 Council, U. N. (2004). Report on the Revitalization of the Counter Terrorism Committee. United Nations.

28. Sasikumar, K. (2010). State agency in the time of the global war on terror: India and the counter-terrorism regime. Review of international studies (36), 615-638.

29. Tasiu Magaji, D. M. (2018, December). INTERROGATING THE NEXUS BETWEEN COUNTERTERRORISM AND HUMAN RIGHTS VIOLATION IN THE NORTH-EASTERN NIGERIA: THE ROLEOF UNCTITF. International Journal of Management Research \& Review.

30. Tufft, B. (2015, January 10). Tory MP wants to scrap Human Rights Act, because Charlie Hebdo. Retrieved from Indy 100: https://www.indy100.com/news/tory-mp-wants-to-scrap-human-rights-actbecause-charlie-hebdo-7256281 